Biota Vol. IX (1): 11-18, Februari 2004

ISSN 0853-8670

\title{
Pemanfaatan Tumbuhan Pangan oleh Masyarakat Talang Mamak di Taman Nasional Bukit Tigapuluh, Jambi
}

\author{
Utilization of Food Plants of Talang Mamak Tribe on Bukit Tigapuluh National Park, \\ Jambi
}

Francisca Murti Setyowati $^{1 *}$ dan Mangasa Hiras Siagian ${ }^{1}$

${ }^{1}$ Bidang Botani, Pusat Penelitian Biologi-LIPI, Bogor. herbogor@indo.net.id *Penulis untuk korespondensi.

\begin{abstract}
An Ethnobotanical study was carried out on a group of Talang Mamak tribe of the Bukit Tigapuluh National Park, Jambi. The inter-relationship and the dependency of the tribe with the forest plant resources were reflected by their daily lives by gathering medicine and hunting. The tribe lives surroundings HPH of the Dalek Esa Raya Co. Ltd. A number of 92 plant species were used as their food. About $70 \%$ of the species recorded were gathered from the forests, and the rest $(30 \%)$ were as cultivated plant. Various botanical aspects of each species with its usage and utilization methods were discussed.
\end{abstract}

Key words : Ethnobotany, Talang Mamak tribe, Bukit Tigapuluh National Park, Jambi, food plants

Diterima: 20 Agustus 2003, disetujui: 7 Juli 2003

\section{Pendahuluan}

Kawasan Taman Nasional Bukit Tigapuluh terletak di perbatasan Propinsi Riau dan Jambi merupakan daerah perbukitan yang mempunyai topografi bergelombang dengan ketinggian sekitar 150-850 $\mathrm{m}$ di atas permukaan laut (dpl). Daerah ini merupakan kawasan hutan hujan tropis yang masih alami. Wilayah ini mempunyai keanekaragaman tumbuhan yang cukup tinggi dan masyarakat yang tinggal di daerah tersebut terdiri dari beberapa suku bangsa antara lain suku Kubu (Anak Dalam), suku Melayu, suku Jawa dan suku Talang Mamak. Dalam tulisan ini akan dibahas mengenai keberadaan suku Talang Mamak yang tinggal di kawasan sekitar Hak Pengelolahan Hutan (HPH) PT. Dalek Esa Raya.

Kelompok orang dari suku Talang Mamak pada umumnya hidup berpencarpencar dengan mata pencaharian dan cara hidup yang relatif sederhana. Sebagian masyarakat di sekitarnya masih meng- golongkan orang Talang Mamak sebagai "masyarakat terasing". Usaha pemerintah untuk meningkatkan taraf hidup orang Talang Mamak antara lain membangun pemukiman menetap untuk mereka. Dalam memenuhi kebutuhan hidup sehari-hari, khususnya bahan pangan mereka masih tergantung pada tumbuhtumbuhan yang ada di sekitarnya. Sebagian besar dari jenis tumbuhan tersebut diambil dari dalam hutan, namun demikian beberapa jenis tumbuhan sudah ada yang ditanam di sekitar tempat pemukiman mereka.

\section{Lokasi penelitian}

Penelitian dilakukan di Dusun Semerantian atau Simarantihan, Desa Suo-Suo yang termasuk Kecamatan Perwakilan Sumai, Kabupaten Bungo-Tebo, Propinsi Jambi. Dusun Semerantian merupakan daerah pemukiman masyarakat Talang Mamak yang sudah mulai menetap di perkampungan yang didirikan pemerintah. Mata pencaharian pokok 
mereka adalah bercocok tanam padi tegalan dengan pola berpindah-pindah dan teknologi sederhana. Mereka juga menanam karet, jagung, ubi kayu dan kacang-kacangan. Mata pencaharian sambilan adalah berburu dan mengumpulkan rotan serta menangkap ikan di sungai atau anak sungai. Jumlah penduduk tercatat sebanyak $16 \mathrm{KK}$ (Kepala Keluarga) dengan 50 jiwa.

\section{Metode Penelitian}

Penelitian dilakukan di luar kawasan Taman Nasional Bukit Tigapuluh Jambi yaitu kawasan hutan alami dan hutan yang berdekatan dengan pemukiman penduduk di mana sebagian besar dari mereka masih tergantung pada hasil hutan. Untuk itu dipilih salah satu daerah pemukiman dari suku Talang Mamak yang yang sudah mulai menetap di suatu lokasi berbatasan dengan kawasan HPH PT. Dalek Esa Raya.

Pengumpulan data di lapangan dilakukan dengan cara observasi serta mengadakan wawancara dengan penduduk setempat yang memanfaatkan tumbuhan dalam kehidupannya sehari-hari terutama dalam hal memenuhi kebutuhan bahan pangan. Tumbuhan tersebut diambil contohnya terutama yang termasuk jenis tumbuhan liar dan selanjutnya dibawa ke Herbarium Bogoriense, Pusat Penelitian Biologi LIPI-Bogor untuk keperluan identifikasi jenis.

\section{Hasil dan Pembahasan}

Penduduk dari Dusun Semerantian, Desa Suo-Suo umumnya mempunyai mata pencaharian bertani dengan sistem perladangan berpindah. Di dalam memenuhi kebutuhan hidup sehari-hari khususnya bahan pangan, masyarakat Talang Mamak mengambil sayuran, buah-buahan, dan lauk pauk seperti babi, ikan dari dalam hutan. Tercatat ada kurang lebih 62 jenis tumbuhan yang diambil dari hutan seperti umbut bayas (Oncosperma horridum), buah keranji (Dialium indum), rukam (Flacourtia rukam), kulim (Scorodocarpus borneensis). Selanjutnya daftar jenis tanaman pangan di lokasi tersebut dirangkum dalam Lampiran 1.

Berbagai jenis rambutan (Nephelium spp.) ditemukan di lokasi seperti rambutan lungkah, rambutan unggul, rambutan aro panjang, rambutan kaki nyamuk, rambutan siyuk, dan mata kucing (Euphoria malaiense). Dari suku Zingiberaceae di antaranya adalah puar kijang (Hornstedtia sp.), puar susu, puar gayat (Alpinia javanica), puar hanyit, puar hitam, puar gasing, puar penyiul, puar tangga, puar tarik, puar telago (Amomum sp.), puar sisip, puar cacing, puar jangon, dan puar kencong.

Beberapa jenis tampoi dimanfaatkan buahnya yaitu tampoi labu (Baccaurea bracteata), tampoi selimatahun (Baccaurea javanica), dan tampoi (Baccaurea sp.). Selain itu ada pula jenis paku-pakuan yang dibuat sayur di antaranya adalah paku tanjung (Asplenium sp.), paku kelat (Thelypteris sp.), dan paku kelemiding (Blechnum orientale).

Tercatat tiga jenis dari famili Anacardiaceae yang buahnya dapat dimakan yaitu binjai (Mangifera caesia), buah putaran (Mangifera rigida), dan singkuang (Dracontomelon dao).

Jenis tanaman yang sudah dibudidayakan oleh masyarakat Talang Mamak tercatat kurang lebih 38 jenis. Berbagai jenis pisang seperti pisang lilin, pisang empat puluh hari, pisang batu, pisang tanduk, pisang pinang, pisang majambon, pisang bunga, pisang jelutung, pisang nangka, pisang rotan, pisang ledi, pisang pipit dan pisang ngiang. Dari famili Zingiberaceae ada empat jenis yaitu lengkuas (Alpinia galanga), jahe (Zingiber officinale), sereh (Andropogon nardus) dan kunyit (Curcuma longa).

Dari famili Convolvulaceae yang dimanfaatkan bagian umbinya yaitu ketela kuning, ketela putih, ketela merah, dan ketela cangkung (Ipomoea batatas). Selain itu dari famili Euphorbiaceae juga ada yang ditanam seperti ubi kapok, ubi mentega dan ubi udang (Manihot esculenta). Jenis buah-buahan yang ditanam seperti belimbing buluh (Averrhoa bilimbi) dan belimbing besi (Averrhoa carambola). Sedangkan jenis sayuran yang diusahakan oleh masyarakat di sini tidak banyak yaitu katuk (Sauropus androgynus), 
kacang panjang (Phaseolus vulgaris), dan terung rimbang (Solanum sp.). Jenis-jenis padi ladang yang ditanam adalah padi (Oryza sativa), padi pulut hitam dan padi pulut putih (Oryza sativa L. var. glutinosa)

Jika dilihat dari bagian tanaman yang dimanfaatkan berturut-turut dari yang terbanyak adalah buah (70 jenis), daun (16 jenis), umbi (10 jenis), selanjutnya diikuti oleh bagian rimpang, umbut, bunga dan batang. Beberapa famili yang jenisnya paling banyak dimanfaatkan adalah Zingiberaceae (17 jenis), Musaceae (13 jenis), Euphorbiaceae (10 jenis), Sapindaceae (8 jenis) dan Poaceae ( 7 jenis). Jenis tambuhan umum yang dijumpai adalah coklat (Theobroma cacao), jagung (Zea mays), tebu (Saccharum officinarum), cabe besar (Capsicum annum), dan cabe kecil (Capsicum frutescens).

Dari 93 jenis tumbuhan yang tercatat, sebagian besar masih tumbuh liar (65 jenis). Hal ini menunjukkan bahwa masyarakat Talang Mamak di lokasi tersebut masih sangat tergantung pada alam di sekitarnya. Beberapa jenis tumbuhan tersebut akan diuraikan daerah penyebaran, nama lokal, kandungan zat makanan, tempat tumbuh dan pemanfaatannya sebagai berikut:

Cempedak hutan (Artocarpus integer), daging buahnya berwarna kuning atau jingga, konsistensinya lembek dan seperti bubur, serta memiliki bau yang khas sekali. Bagian yang dimakan adalah daging buah yang matang dapat sebagai buah segar atau diolah, bijinya dimakan setelah dibakar atau direbus dan rasanya seperti kacang. Buah muda dimasak dengan santan sebagai sayur atau sop nangka muda. Daun muda juga digunakan sebagai sayur. Disamping itu, kayunya mengandung banyak tanin $\pm 8 \%$ dari berat kering (Jansen, 1997).

Terap (Artocarpus odoratissimus), buahnya yang berukuran besar itu disenangi karena daging buahnya manis, banyak mengandung sari buah dan harum baunya. Buah ini memiliki rasa yang lebih enak daripada nangka. Bijinya juga dapat dimakan setelah dibakar atau direbus. Buah mudanya dapat dibuat sayur dengan ditambah santan (de la Cruz, 1997).
Baccaurea motleyana, berasal dari Sumatera, Kalimantan dan Jawa. Buahnya dapat dimakan segar tetapi karena asam maka sering dimanfaatkan untuk asinan, setup ataupun difermentasi menjadi anggur (Uji, 1997).

Singkuang (Dracontomelon dao) mempunyai beberapa nama daerah sebagai berikut, Indonesia: dau (Jawa), singkuang (Kalimantan), dan dar (Irian Jaya). Malaysia: singkuang. Papua Nugini: New Guinea Walnut. Filipina: peldao, Thailand: ka-kho, sang-kuan. Buah dapat dimakan sebagai lalap, kulit batang digunakan sebagai obat tradisional untuk merangsang aborsi.

Bunai (Antidesma pentandrum), buahnya dimakan segar, rasanya asam. Mempunyai perawakan berupa perdu atau pohon kecil dengan ranting berwarna coklat sampai kuning. Buah bertipe buah batu, berbentuk bulat telur sampai jorong, warna merah jambu sampai merah. Tumbuh di semak-semak di dataran rendah sampai sedang dan pada ketinggian $1800 \mathrm{~m} \mathrm{dpl}$.

Tampoi labu (Baccaurea bracteata), dengan beberapa nama daerah sebagai berikut, Indonesia: pangal, Malaysia: rambai hutan, tampoi bunga, tampoi kera paya. Daerah penyebarannya adalah Semenanjung Thailand, Semenanjung Malaysia, Sumatera, Kalimantan. Perawakannya berupa pohon dengan tinggi mencapai $20 \mathrm{~m}$. Buahnya dapat dimakan tetapi rasanya asam. Umum dijumpai di hutan rawa, hutan gambut, di dataran rendah.

Binjai (Mangifera caesia), buahnya banyak mengandung sari buah dan rasanya asam manis, dapat dikonsumsi segar setelah buahnya matang. Buah ini seringkali digunakan untuk membuat sambal yang dimakan dengan ikan sungai. Kurang lebih 65\% dari keseluruhan buah binjai dapat dimakan. Dan setiap $100 \mathrm{~g}$ bagian yang dapat dimakan mengandung 86,5 g air, $1 \mathrm{~g}$ protein, 0,2 g lemak, 11,9 g karbohidrat, 0,4 g abu, 0,08 $\mathrm{mg}$ tiamina, $0,005 \mathrm{mg} \beta-$ karotena dan $58 \mathrm{mg}$ vit. C dengan nilai energi $200 \mathrm{KJ} / 100 \mathrm{~g}$. (Bompard, 1997). Umumnya binjai tumbuh di dataran-dataran rendah di kawasan tropik basah di bawah ketinggian $400 \mathrm{~m}$ dpl. Musim buah terjadi pada musim penghujan yaitu mulai bulan Nopember sampaiMaret, sedang musim 
berbunganya mulai bulan Oktober sampai Desember (Uji, et al., 1998).

Rukam (Flacourtia rukam), mempunyai perawakan pohon kecil dengan tinggi 5 sampai $20 \mathrm{~m}$. Buahnya bertipe buah buni yang bentuknya bulat, bulat gepeng sampai bulat telur sungsang, berwarna hijau muda sampai merah jambu atau hijau lembayung sampai merah tua, berdaging keputih-putihan, dan banyak mengandung air yang rasanya asam. Analisa per $100 \mathrm{~g}$ bagian yang dapat dimakan di Filipina menunjukkan perbandingan sebagai berikut: $77 \mathrm{~g}$ air, $1,7 \mathrm{~g}$ protein, 1,3 g lemak, $15 \mathrm{~g}$ karbohidrat, 3,7 $\mathrm{g}$ serat, $0,8 \mathrm{~g}$ abu serta mempunyai nilai energi $345 \mathrm{KJ} / 100 \mathrm{~g}$ (Sunarjono, 1997). Sedangkan menurut Uji, et al. (1998) bahwa buahnya dapat dimakan langsung namun agak asam dan biasanya dibuat rujak, asinan, dan jam. Buah yang belum masak digunakan untuk mengobati diare dan desentri, sedangkan daun mudanya dapat juga dimakan. Kayunya dapat juga sebagai bahan bangunan rumah dan pembuatan mebel.

Rambutan cina (Passiflora foetida) diduga berasal dari Amerika Selatan, saat ini dibudidayakan dan seringkali meliar kembali di berbagai negara tropik, juga di Asia Tenggara. Buahnya yang matang dimakan dalam keadaan segar, rasanya manis dan mengandung banyak sari buah. Tetapi buah yang belum matang mengandung racun. Tumbuhan ini juga dipakai sebagai tanaman pagar dan sebagai tanaman penutup tanah pada usaha pertanian. Mempunyai perawakan terna memanjat, buahnya bertipe buah buni, berbentuk agak bulat, sering menjadi gulma dan tumbuh sampai ketinggian $1500 \mathrm{~m} \mathrm{dpl}$.

$$
\text { Gelugur (Garcinia griffithii) }
$$

berperawakan pohon dengan tinggi $12-18 \mathrm{~m}$. Daunnya berbentuk jorong melebar, berukuran $(22-40) \quad \mathrm{cm} \quad x \quad(10-20) \quad \mathrm{cm}$. Bunganya berkelamin tunggal, berwarna kekuningan, sedangkan daun mahkotanya berwarna kemerahan di pangkalnya. Buahnya bertipe buah buni, berbentuk bulat, berdiameter 5-8 $\mathrm{cm}$, mirip buah apel hijau, kemudian lama kelamaan menjadi kuning-coklat. Umumnya terdapat di hutan dataran rendah.

Pometia pinnata mempunyai beberapa nama daerah sebagai berikut, Indonesia: kasai, matoa, leungsir (Jawa), tawan (Maluku), ihi mendek (Irian Jaya); Malaysia: sibu; Papua Niugini: taun; Thailand: sai; Filipina: malugai. Sampai saat ini belum diketahui asal usulnya. Berbentuk pohon dengan tinggi mencapai $40 \mathrm{~m}$ dengan garis tengah batang $100 \mathrm{~cm}$. Buahnya mempunyai aril yang rasanya manis. Bijinya bisa dimakan. Kayu digunakan untuk berbagai keperluan seperti untuk perahu, lantai rumah, peralatan olah raga dan pertanian. Juga bagus untuk pembuatan arang. Daun dan kulit batang dapat dimanfaatkan untuk mengobati demam. Musim berbunga dan berbuahnya belum diketahui (Uji, et al.,1998).

Rambutan siyuk (Nephelium ramboutan Ake), daerah penyebarannya meliputi India (Assam), Myanmar, Indonesia, Malaysia dan Filipina. Buah ini per $100 \mathrm{~g}$ bagian yang dapat dimakan mengandung $85 \mathrm{~g}$ air, $0,8 \mathrm{~g}$ protein, $0,6 \mathrm{~g}$ lemak, $13 \mathrm{~g}$ karbohidrat, $0,1 \mathrm{~g}$ serat dan $0,4 \mathrm{~g}$ abu. Tumbuhan ini terutama dijumpai di hutan primer dataran rendah, seringkali di pinggiran sungai, tetapi jarang sekali tumbuh di rawa-rawa, dan menyenangi tanah pasir atau tanah lempung (Seibert, 1997).

Belimbing buluh (Averrhoa bilimbi) dan belimbing besi (Averrhoa carambola). Belimbing buluh digunakan untuk pembuatan acar, kari, chutney, dan diawetkan dalam bentuk sirup. Buah belimbing manis dimakan dalam keadaan segar, sebagai sari buah, rujak, selai, agar-agar, lalapan. Kedua jenis belimbing ini juga digunakan untuk membersihkan logam dan menghilangkan karat serta untuk ramuan berbagai ramuan obat tradisional seperti obat demam dan kulit. Rasa asam belimbing buluh terutama ditentukan oleh asam sitrat, sedangkan belimbing manis didominasi oleh asam oksalat. Keduanya kaya akan kalium dan vitamin $\mathrm{A} ;$ kandungan vitamin $\mathrm{C}$ pada belimbing buluh rendah, sedangkan pada belimbing manis sedang-sedang saja (Samson, 1997).

Ada tiga jenis gadung yang dimanfaatkan umbinya untuk bahan pangan yaitu Dioscorea esculenta, Dioscorea hispida dan Dioscorea bulbifera. Rata-rata gadung mempunyai kadar zat tepung $21 \%$. Menurut berat kering kandungan karbohidratnya $77 \%$, albumin $10 \%$ dan lemak 1-1,9\%. Kandungan mineralnya untuk setiap $100 \mathrm{~g}$ adalah kalsium $45 \mathrm{mg}$, fosfor $280 \mathrm{mg}$, besi 1,8 mg. Kandungan 
vitamin B dan vitamin C lebih sedikit daripada kentang. Secara keseluruhan gadung sebagai bahan pangan non beras nilainya hampir setaraf dengan kentang (Schery, 1958).

Dioscorea hispida (gadung) setiap $100 \mathrm{~g}$ umbi yang dapat dimakan, mengandung $77 \mathrm{~g}$ air, $1,81 \mathrm{~g}$ protein, $1,6 \mathrm{~g}$ lemak, $18 \mathrm{~g}$ karbohidrat, 1,9 g serat dan 0,7 g abu. Dalam keadaan kering umbi mengandung racun diosgenin $(0,2-0,7 \%)$ dan dioscorin $(0,044$ $\%)$. Kedua racun ini dapat menyebabkan paralisis pada susunan syaraf pusat. Ekstrak tepung yang diperdagangkan mengandung: $88,34 \%$ tepung, $5,28 \%$ protein, $5,33 \%$ serat, $0,23 \%$ lemak dan 0,66\% abu (Rahayu, 1998). Ekstrak tersebut dapat digunakan untuk masakan atau industri khususnya pabrik glukosa. Racun dari umbi sering diekstrak dan digunakan sebagai umpan binatang. Umbi yang ditumbuk dapat digunakan sebagai antiseptik dan rebusannya diminum untuk mengurangi rematik yang kronis (Onwueme, 1996).

Dioscorea esculenta dengan komposisi per 100 gr umbi terdiri dari air $70-80 \mathrm{~g}$, protein 1,3-2,1 g, lemak 0,1-0,3 g, karbohidrat 26-38 g, serat $0,2-1,5 \mathrm{~g}$, abu 0,5-1,2 g, vitamin A 0,017 $\mathrm{mg}$, vitamin B1 0,08 mg, vitamin B2 0,02 mg dan vitamin C 20,3 mg (Susiarti, 1998). Umbi dimakan sebagai bahan pokok yang mengandung karbohidrat, setelah dimasak atau dipanggang dan rasanya manis dan sedap. Juga digunakan sebagai diet khusus untuk orangorang penderita penyakit saluran pencernaan. Parutan umbi mentahnya digunakan dalam pengobatan sebagai tapal pada bengkakbengkak, khususnya pada leher (Onwueme, 1996).

Dioscorea bulbifera per $100 \mathrm{~g}$ bahan yang dimakan mengandung air 63-67 g, protein 1,12-1,50 g, lemak 0,04 g, karbohidrat 27-33 g, serat $0,70-0,73 \mathrm{~g}$ dan abu $1,08-1,51 \mathrm{~g}$. Zat tepung dari umbi berisi $13,5 \%$ uap lembab, $15,0 \%$ amilase, $1,49 \%$ protein, $0,29 \%$ abu, $\mathrm{pH}$ 4,4 dan Iod absorbsi 3,9\%. Umbi yang diperoleh dari tumbuhan liar harus terlebih dulu dikupas, diiris, dicuci, kemudian direbus dalam waktu yang lama dan kadang-kadang direndam dalam air mengalir untuk menghilangkan racunnya sebelum umbi tersebut dimakan (Onwueme, 1996).
Jagung (Zea mays) setiap $100 \mathrm{~g}$ terdiri dari $10 \mathrm{~g}$ air, $10 \mathrm{~g}$ protein, 4,5 g lemak, $70 \mathrm{~g}$ karbohidrat, $2 \mathrm{~g}$ serat, $2 \mathrm{~g}$ abu dengan nilai energi rata-rata $1525 \mathrm{~kJ} / 100 \mathrm{~g}$ (Windadri, 1998).

\section{Kesimpulan}

Dari hasil penelitian pada masyarakat Talang Mamak di Taman Nasional Bukit Tigapuluh, Jambi tercatat ada 93 jenis tumbuhan yang dimanfaatkan sebagai bahan pangan. Dari jumlah tersebut $70 \%$ nya masih diambil dari hutan dan sisanya $30 \%$ sudah merupakan tanaman budidaya. Jenis tumbuhan yang banyak dimanfaatkan sebagai bahan pangan adalah famili Zingiberaceae, Musaceae, Euphorbiaceae, Sapindaceae, Fabaceae dan Moraceae.

Bagian tumbuhan yang dimanfaatkan berturut-turut dari yang terbanyak adalah buah (70 jenis), daun (15 jenis), umbi (10 jenis), rimpang ( 3 jenis), umbut ( 2 jenis), bunga (1 jenis), dan batang (1 jenis).

Masyarakat Talang Mamak di TNBT, Jambi mengkonsumsi jenis-jenis gadung (Dioscorea spp.) sebagai makanan pokoknya, nilai gizi gadung tersebut hampir setaraf dengan kentang sehingga tidak perlu dikhawatirkan mereka akan kekurangan gizi.

\section{Daftar Pustaka}

Bompard, J.M. 1997. Mangifera caesia Jack. Dalam : Verheij, E.W.M. and R.E. Coronel (Eds.). 1997. PROSEA Sumber Daya nabati Asia Tenggara 2. Buah-Buahan Yang Dapat Dimakan. PT. Gramedia Pustaka Utama, Jakarta. Hal. 261-263.

de la Cruz, F.S. 1997. Artocarpus odoratissimus Blanco. Dalam : Verheij, E.W.M. and R.E. Coronel (Eds.). 1997. PROSEA Sumber Daya nabati Asia Tenggara 2. Buah-Buahan Yang Dapat Dimakan. PT.Gramedia Pustaka Utama, Jakarta. Hal. 106-109. 
Jansen, P.C.M. 1997. Artocarpus integer (Thunb.) Merr. Dalam : Verheij, E.W.M. and R.E. Coronel (Eds.). 1997. PROSEA Sumber Daya nabati Asia Tenggara 2. Buah-Buahan Yang Dapat Dimakan. PT.Gramedia Pustaka Utama, Jakarta. Hal. 103-106.

Onwueme, I.C. 1996. Dioscorea hispida. In : Flach, M. and F. Rumawas (Eds.) 1996. PROSEA No.9. Plant Yielding Non-Seed Carbohydrates. Backhuys Publishers, Leiden. 237 pp.

Rahayu, M. 1998. Gadung (Dioscorea hispida Dennst.). Dalam : Sutarno, $H$. and S. Atmowidjojo (Eds.). 1998. Seri Pengembangan PROSEA 9.1. Mengenal Lahan Kering and Prospek Pengembangan Usaha Tani Tanaman Penghasil Karbohidrat di NTT. Hal. 27-28.

Samson, J.A. 1997. Averrhoa L. Dalam : Verheij, E.W.M. and R.E. Coronel (Eds.). 1997. PROSEA Sumber Daya nabati Asia Tenggara 2. Buah-Buahan Yang Dapat Dimakan. PT. Gramedia Pustaka Utama, Jakarta. Hal. 109-112.

Schery, R.W. 1958. Plants for Man. Prentice Hall, New Jersey.

Seibert, B. 1997. Nephelium L. Dalam : Verheij, E.W.M. and R.E. Coronel (Eds.). 1997. PROSEA Sumber Daya nabati Asia Tenggara 2. Buah-Buahan Yang Dapat Dimakan. PT. Gramedia Pustaka Utama, Jakarta. Hal. 296-299.
Sunarjono, H.H. 1997. Flacourtia rukam Zoll. and Moritzi. Dalam : Verheij, E.W.M. \& R.E. Coronel (Eds.). 1997. PROSEA Sumber Daya nabati Asia Tenggara 2. Buah-Buahan Yang Dapat Dimakan. PT.Gramedia Pustaka Utama, Jakarta. Hal. 206-208.

Susiarti, S. 1998. Ubi gembili (Dioscorea esculenta (Lour.) Burkill). Dalam: Sutarno, H. \& S. Atmowidjojo (Eds.). 1998. Seri Pengembangan PROSEA 9.1. Mengenal Lahan Kering \& Prospek Pengembangan Usaha Tani Tanaman Penghasil Karbohidrat di NTT. Hal. 34-35.

Uji, T. 1997. Baccaurea Lour. Dalam : Verheij, E.W.M. and R.E. Coronel (Eds.). 1997. PROSEA Sumber Daya nabati Asia Tenggara 2. Buah-Buahan Yang Dapat Dimakan. PT.Gramedia Pustaka Utama, Jakarta. Hal. 112-115.

Uji, T. 1998. Buah-buahan Bengkulu. Proyek Litbang dan Pendayagunaan Potensi Wilayah Puslitbang Biologi LIPI, Bogor. 100 hal.

Windadri, F.I. 1998. Jagung (Zea mays L.). Dalam : Sutarno, H. and S. Atmowidjojo (Eds.). 1998. Seri Pengembangan PROSEA 9.1. Mengenal Lahan Kering \& Prospek Pengembangan Usaha Tani Tanaman Penghasil Karbohidrat di NTT. Hal. 29-30.

Lampiran 1. Jenis-jenis Tumbuhan Pangan Di Taman Nasional Bukit Tigapuluh, Jambi.

\begin{tabular}{|c|c|c|c|c|}
\hline No. & Nama Lokal & Nama Jenis & Famili & Bagian Berguna \\
\hline 1. & Ara padi & Ficus grosularioides Burm. & Moraceae & Daun muda \\
\hline 2. & Aro rambai & Baccaurea motleyana M.A. & Euphorbiaceae & Buah \\
\hline 3. & Balam sungkup & Palaquium hexandrum Engl. & Sapotaceae & Buah \\
\hline 4. & Bayas & Oncosperma horridum Scheff. & Arecaceae & Umbut \\
\hline 5. & Belimbing besi & Averrhoa carambola $\mathrm{L}$. & Oxalidaceae & Buah \\
\hline 6. & Belimbing buluh & Averrhoa bilimbi $\mathrm{L}$. & Oxalidaceae & Buah \\
\hline 7. & Binjai & Mangifera caesia Jack & Anacardiaceae & Buah \\
\hline 8. & Buah kedengkang & Ficus sp. & Moraceae & Buah, daun muda \\
\hline 9. & Buah putaran & Mangifera rigida & Anacardiaceae & Buah \\
\hline 10. & Bunai & Antidesma tetandrum $\mathrm{Bl}$. & Euphorbiaceae & Buah \\
\hline 11. & Cabe besar & Capsicum annum $\mathrm{L}$. & Solanaceae & Buah \\
\hline 12. & Cabe kecil & Capsicum frutescens $\mathrm{L}$. & Solanaceae & Buah \\
\hline 13. & Cempedak hutan & Artocarpus integra Merr. & Moraceae & Buah \\
\hline 14. & Coklat & Theobroma cacao L. & Sterculiaceae & Buah \\
\hline 15. & Duren musim & Durio zibethinus Murr. & Bombacaceae & Buah \\
\hline 16. & Gadung & Dioscorea bulbifera $\mathrm{L}$. & Dioscoreaceae & Umbi \\
\hline
\end{tabular}




\begin{tabular}{|c|c|c|c|c|}
\hline No. & Nama Lokal & Nama Jenis & Famili & Bagian Berguna \\
\hline 17. & Gadung & Dioscorea esculenta (Lour.) Burk. & Dioscoreaceae & Umbi \\
\hline 18. & Gadung & Dioscorea hispida Dennstedt & Dioscoreaceae & Umbi \\
\hline 19. & Gelugur & Garcinia griffithii $\mathrm{T}$. Andrers & Clusiaceae & Buah \\
\hline 20. & Gitan & Willughbeia cf. firma $\mathrm{Bl}$. & Apocynaceae & Buah \\
\hline 21. & Jagung & Zea mays $\mathrm{L}$. & Poaceae & Buah \\
\hline 22. & Jahe & Zingiber officinale Rosc. & Zingiberaceae & Rimpang \\
\hline 23. & Jengkol & Archidendron pauciflorum (Benth.) Nielsen & Fabaceae & Daun muda, buah \\
\hline 24. & Kabau & Pithecellobium bubalinum (Jack) Benth. & Fabaceae & Buah \\
\hline 25. & Kacang panjang & Vigna sinensis $\mathrm{L}$. & Fabaceae & Buah \\
\hline 26. & Kasai & Pometia pinnata Forst. & Sapindaceae & Buah \\
\hline 27. & Katuk & Sauropus androgynus (L.) Merr. & Euohorbiaceae & Daun muda \\
\hline 28. & Keranji & Dialium indum $\mathrm{L}$. & Fabaceae & Buah \\
\hline 29. & Ketelo cangkung & Ipomoea batatas (L.) Lam. & Convolvulaceae & Umbi \\
\hline 30. & Ketelo kuning isi & Ipomoea batatas (L.) Lam. & Convolvulaceae & Umbi \\
\hline 31. & Ketelo merah isi putih & Ipomoea batatas (L.) Lam. & Convolvulaceae & Umbi \\
\hline 32. & Ketelo putih & Ipomoea batatas (L.) Lam. & Convolvulaceae & Umbi \\
\hline 33. & Kulim & Scorodocarpus borneensis Becc. & Olacaceae & Buah \\
\hline 34. & Kunyit & Curcuma longa $\mathrm{L}$. & Zingiberaceae & Rimpang \\
\hline 35. & Lengkuas & Alpinia galanga $\mathrm{SW}$. & Zingiberaceae & Rimpang \\
\hline 36. & Mata kucing & Euphoria malaiense Radlk. & Sapindaceae & Buah \\
\hline 37. & Melabai & Macaranga gigantea M.A. & Euphorbiaceae & Umbut \\
\hline 38. & Padi Bimas & Oryza sativa $\mathrm{L}$. & Poaceae & Buah \\
\hline 39. & Padi gogo & Oryza sativa $\mathrm{L}$. & Poaceae & Buah \\
\hline 40. & Padi pulut hitam & Oryza sativa $\mathrm{L}$. var. glutinosa & Poaceae & Buah \\
\hline 41. & Padi pulut putih & Oryza sativa $\mathrm{L}$. var. glutinosa & Poaceae & Buah \\
\hline 42. & Paku kelat & Thelypteris sp. & Polypodiaceae & Daun muda \\
\hline 43. & Paku kelemiding & Blechnum orientale $\mathrm{L}$. & Polypodiaceae & Daun muda \\
\hline 44. & Paku tanjung & Asplenium sp. & Polypodiaceae & Daun muda \\
\hline 45. & Petai & Parkia javanica (Lamk.) Merr. & Fabaceae & Buah \\
\hline 46. & Petaling & Ochanostachys amentaceae Mast. & Olacaceae & Buah \\
\hline 47. & Pisang 40 hari & Musa sp. & Musaceae & Buah \\
\hline 48. & Pisang batu & Musa sp. & Musaceae & Buah \\
\hline 49. & Pisang bunga & Musa sp. & Musaceae & Buah \\
\hline 50. & Pisang bunga jelutung & Musa sp. & Musaceae & Buah \\
\hline 51. & Pisang ledi & Musa sp. & Musaceae & Buah \\
\hline 52. & Pisang lilin & Musa sp. & Musaceae & Buah \\
\hline 53. & Pisang majambon & Musa sp. & Musaceae & Buah \\
\hline 54. & Pisang nangka & Musa sp. & Musaceae & Buah \\
\hline 55. & Pisang ngiang & Musa sp. & Musaceae & Buah \\
\hline 56. & Pisang pinang & Musa sp. & Musaceae & Buah \\
\hline 57. & Pisang pipit & Musa sp. & Musaceae & Buah \\
\hline 58. & Pisang rotan & Musa sp. & Musaceae & Buah \\
\hline 59. & Pisang tanduk & Musa sp. & Musaceae & Buah \\
\hline 60. & Puar cacing & - & Zingiberaceae & Buah \\
\hline 61. & Puar gasing & - & Zingiberaceae & Buah \\
\hline 62. & Puar gayat & Alpinia javanica Bl. & Zingiberaceae & Buah \\
\hline 63. & Puar hanyit & - & Zingiberaceae & Buah \\
\hline 64. & Puar hitam & Etlingera cf. punicea & Zingiberaceae & Buah \\
\hline 65. & Puar jangon & - & Zingiberaceae & Buah \\
\hline 66. & Puar kencong & - & Zingiberaceae & Bunga, buah \\
\hline 67. & Puar kijang & Etlingera sp. & Zingiberaceae & Buah \\
\hline 68. & Puar penyiul & - & Zingiberaceae & Buah \\
\hline 69. & Puar sisip & Etlingera elatior (Jack) R.M. Smith & Zingiberaceae & Buah \\
\hline 70. & Puar susu & Hornstedtia sp. & Zingiberaceae & Buah \\
\hline
\end{tabular}


Pemanfaatan Tumbuhan Pangan Masyarakat Talang Mamak

\begin{tabular}{|c|c|c|c|c|}
\hline No. & Nama Lokal & Nama Jenis & Famili & Bagian Berguna \\
\hline 71. & Puar tangga & - & Zingiberaceae & Buah \\
\hline 72. & Puar tarik & - & Zingiberaceae & Buah \\
\hline 73. & Puar telago & Атотит sp. & Zingiberaceae & Buah \\
\hline 74. & Pulai & Alstonia scholaris R.Br. & Apocynaceae & Daun muda \\
\hline 75. & Rambutan & Nephelium lappaceum L. var.1 & Sapindaceae & Buah \\
\hline 76. & Rambutan aro panjang & Nephelium lappaceum L. var.4 & Sapindaceae & Buah \\
\hline 77. & Rambutan cina & Passiflora foetida $\mathrm{L}$. & Passifloraceae & Buah \\
\hline 78. & Rambutan kaki nyamuk & Nephelium lappaceum L. var.5 & Sapindaceae & Buah \\
\hline 79. & Rambutan lungkah & Nephelium lappaceum L. var.2 & Sapindaceae & Buah \\
\hline 80. & Rambutan siyuk & Nephelium ramboutan-ake Leenh. & Sapindaceae & Buah \\
\hline 81. & Rambutan unggul & Nephelium lappaceum L. var.3 & Sapindaceae & Buah \\
\hline 82. & Rukam & Flacourtia rukam Z.\& M. & Flacourtiaceae & Buah \\
\hline 83. & Semantung & Ficus padana & Moraceae & Daun muda \\
\hline 84. & Serai kayu & Eugenia acuminatissima Kurz & Myrtaceae & Daun muda \\
\hline 85. & Sereh & Andropogon nardus $\mathrm{L}$. & Poaceae & Daun \\
\hline 86. & Sibekal & Fordia sp. & Fabaceae & Daun muda \\
\hline 87. & Simpur & Dillenia excelsa (Jack) Gilg. & Dilleniaceae & Daun muda \\
\hline 88. & Singkuang & Dracontomelon dao (Blanco) Merr. \& Rolfe & Anacardiaceae & Buah \\
\hline 89. & Tampoi & Baccaurea sp. & Euphorbiaceae & Buah \\
\hline 90. & Tampoi labu & Baccaurea bracteata M.A. & Euphorbiaceae & Buah \\
\hline 91. & Tampoi selimatahun & Baccaurea javanica M.A. & Euphorbiaceae & Buah \\
\hline 92. & Tebu & Saccharum officinarum $\mathrm{L}$. & Poaceae & Batang \\
\hline 93. & Terap & Artocarpus odoratissimus Blanco & Moraceae & Buah \\
\hline 94. & Terung rimbang & Solanum sp. & Solanaceae & Buah \\
\hline 95. & Turangsi & - & - & Daun muda \\
\hline 96. & Ubi kapuk & Manihot esculenta Crantz. & Euphorbiaceae & Umbi \\
\hline 97. & Ubi mentega & Manihot esculenta Crantz. & Euphorbiaceae & Umbi \\
\hline 98. & Ubi udang & Manihot esculenta Crantz. & Euphorbiaceae & Umbi \\
\hline
\end{tabular}

